\title{
The use of medicinal plants by an indigenous Pataxó community in NE Brazil
}

\author{
CUNHA LIMA, S.T. ${ }^{1 *}$; RODRIGUES, E.D. ${ }^{2}$; ALVES, C. ${ }^{3}$ MERRIGAN, T.L. ${ }^{4}$ MELO, T. ${ }^{5}$; GUEDES, M.L.S. ${ }^{6}$; \\ NASCIMENTO, A.F. ${ }^{6}$; TORALLES, M.B. ${ }^{3}$ \\ ${ }^{1}$ Universidade Federal da Bahia (UFBA), Departamento de Biologia Geral, Instituto de Biologia, Rua Barão de \\ Jeremoabo, s/n, Campus Universitário de Ondina, CEP: 40170-115, Salvador-Brasil * stcunhalima@ufba.br \\ ${ }^{2}$ Centro Universitário Estácio da Bahia. Rua Xingu, 179, CEP: 41770-130, Stiep, Salvador-Brasil ${ }^{3}$ UFBA, Prof. \\ Edgard Santos Hospital (HUPES), CEP: 41940-060, Salvador-Brasil ${ }^{4}$ Community Colleges of Spokane, 1810 N, \\ Greene St., Spokane, WA, 99217, USA ${ }^{5}$ Universidade Católica do Salvador (UCSAL), Avenida Prof. Pinto de \\ Aguiar, 2589, Pituaçu, CEP: 41740-090, Salvador-Brasil ${ }^{6}$ UFBA, Departamento de Botânica, Instituto de Biologia, \\ Rua Barão de Jeremoabo, s/n, Campus Universitário de Ondina, CEP: 40170-115, Salvador-Brasil * stcunhalima@ \\ ufba.br
}

\begin{abstract}
We identified and classified 48 medicinal plants used by the Pataxó Indians in south Bahia, Brazil. The location is an ecologically threatened area designated by UNESCO as a World Heritage Site. The aim of this paper is to document phytotherapeutic practices in the indigenous community of Mata Medonha. We conducted interviews with the 25 families present at the area. Of the 48 medicinal species identified, only $14(29 \%)$ had been examined for mechanism of action or isolation of biochemical compounds, according to bibliographic research. The plants were deposited at the Alexandre Leal Costa Herbarium of the Federal University of Bahia. We gathered information about the preparation and uses of the plants. The species are used for a variety of maladies, including flu, congestion, bronchitis and headaches, pain, snake bites, and some were only used for women's disorders. The Pataxó ethnopharmacological knowledge is under pressure from the economic outmigration of the community and threats to the biodiversity from logging, mining, and tourism. The plants studied here include important drug candidates. Additional research on the molecular aspects of the species cited should be performed.
\end{abstract}

Key words: medicinal plants, indigenous community, ethnobotany, Pataxó, Bahia

RESUMO: O uso de plantas medicinais por uma comunidade indígena Pataxó no NE do Brasil. Foram identificadas e classificadas 48 plantas medicinais usadas por Índios Pataxós no sul da Bahia. A região é área de risco ecológico designada pela UNESCO como Sítio do Patrimônio Mundial. O objetivo deste estudo foi de documentar as práticas fitoterápicas na comunidade indígena da Mata Medonha. Foram conduzidas entrevistas com as 25 famílias presentes no local. Dentre as 48 espécies identificadas, apenas 14 (29\%) foram avaliadas quanto ao mecanismo de ação ou isolamento de compostos químicos, de acordo com levantamento bibliográfico. As plantas foram depositadas no Herbário Alexandre Leal Costa da Universidade Federal da Bahia. Foram registradas informações sobre o preparo e uso das plantas citadas. As espécies são usadas para uma variedade de doenças incluindo gripe, congestão, bronquite, dores em geral, picadas de cobra e algumas apenas para doenças femininas. O conhecimento etnofarmacológico Pataxó está sobre pressão pelas migrações para fora da comuindade e ameaças à biodiversidade por desmatamento, mineração e turismo. As plantas estudadas incluem importantes candidatos a fármacos. Pesquisas adicionais sobre os aspectos moleculares devem ser realizadas.

Palavras-chave: plantas medicinais, comunidade indígena, etnobotânica, Pataxó, Bahia

\section{INTRODUCTION}

With over 120,000 species, Brazil is an empire of plants (Ferro, 2006). Brazilian plants have been used since ancient times in traditional medicine
(Almeida, 1999) and native Brazilians possess deep knowledge of the therapeutic properties of local flora. Our studies took place in the rainforests of Bahia

Recebido para publicação em 28/06/2010

Aceito para publicação em 29/08/2011

Rev. Bras. PI. Med., Botucatu, v.14, n.1, p.84-91, 2012. 
State, which have been designated a World Heritage Site by United Nations Educational, Scientific and Cultural Organization (UNESCO, 1999). The rainforests of Brazil's Atlantic coast are the world's richest in terms of biodiversity. The site contains a distinct range of species with a high level of endemism and reveals a pattern of evolution that is not only of great scientific interest but is also of importance for conservation.

Many studies were made on the healing flora used in Brazil's traditional medicinal practices, among them are the research of the medicinal plants used by the Pataxós of Monte Pacoal, analyzed by Thomas (2001); the study of Rodrigues \& Carlini (2005) who analyzed the 'Krahô tribes' use of plants affecting the central nervous system; Morais et al. (2005) that described the use of medicinal plants by the Tapeba tribe of Ceará; Coutinho et al. (2002) who studied the medicinal use of the flora by Indian Communities from Maranhão; Begossi (1996) and Begossi et al. $(2000 ; 2002)$ who studied the medicinal plants in the Atlantic Forest, focusing on knowledge of the caiçaras (rural inhabitants of the Brazil's Atlantic coast); and Milliken \& Albert (1996; 1997) the medicinal plants used by the Yanomami Indians. In a wider study, the medicinal and poisonous plants used in NE region of Brazil were described from Maranhão to the state of Bahia in a recent survey (Agra et al., 2007; 2008).

In southern Bahia, the remaining coastal forests occupy a belt approximately $100-200 \mathrm{~km}$ wide along the Atlantic coast. The forests gradually become drier inland, changing from the littoral restinga forest to the southern Bahian moist forest, to semideciduous forest, to the deciduous liana forest ("Mata de Cipó") (Gouvêa, 1976). Each of these forest types occupies a narrow zone up to $50 \mathrm{Km}$ wide within the coastal forest belt and varies in composition depending on elevation, soils, and drainage. Farther inland, the vegetation changes from forest to grassland (Cerrado) or dry thorn scrub (Caatinga). Above 600-700 m elevation, the forests become cooler and more humid. Within the southern Bahian moist forest zone, variation in soils and topography results in a patchwork of diverse micro-habitats within the superficially uniform forest.

The distributions of many species of plants and animals are restricted to areas between the large river systems that drain the Atlantic coastal forest of southern Bahia. These rivers apparently act as barriers to the migration of many species of plants and animals and, consequently, many species may be endemic to one of these interfluvial zones (Thomas, 2003).

Brazil has a rich indigenous heritage, including 225 Indian nations, 68 of whom have never been contacted. Yet only 460,000 natives still live in traditional villages, with 100-190 thousand more in urban areas (FUNAI, 2009). With approximately 2,250 individuals remaining, the Pataxó are a small indigenous group that lives in the extreme southeast of the Brazilian state of Bahia. Their territory covers 8,640 ha of land between the Mucuri and João de Tiba Rivers, and the Atlantic Ocean.

Pataxós live on subsistence agriculture, small-scale fresh fishing, and the sale of utilitarian artisan products in nearby villages. They are scattered and shrinking due to modern diseases, encroachment tourism and mining (Curi, 2005). The Pataxó are losing both their native language - most speak exclusively Portuguese - and their knowledge of traditional medicine. Their botanical knowledge is in danger of disappearing, as has been seen in other indigenous communities in Brazil.

The Pataxó occupation of the south part of Bahia initiated in 1805. The group was gathered in a village called Barra Velha, at Monte Pacoal (Pascoal Mount), together with many other Indian groups, as the Maxakali, Botocudos, Camakã and Tupiniquim. Monte Pascoal, a peak $586 \mathrm{~m}$ high, was the first land sighted when the Portuguese discovered Brazil in 1500. The Park was dedicated in 1961 at which time it covered 22,500 ha; the area was later reduced to 14,000 ha, with most of the excluded territory given to the local Pataxós Indian tribe (Pádua, 1989). The park lies $250 \mathrm{~km}$ south of Ilhéus and extends westward from the coast $30 \mathrm{~km}$ to Monte Pascoal (16 ${ }^{\circ} 53^{\prime}-16^{\circ} 58^{\prime} \mathrm{S}$, $\left.39^{\circ} 07^{\prime}-39^{\circ} 25^{\prime} \mathrm{W}\right)$. The area receives approximately $1500-1750 \mathrm{~mm}$ per year of rainfall with $1-2$ dry months per year. Annual temperatures average $22-24^{\circ} \mathrm{C}$ (IBAMA, 2009). The vegetation of the eastern part of the Park is restinga and mangrove and of the western part, southern Bahian wet forest over laterite. Many small Indian communities leaved Barra Velha after creation of the Park, and occupied other regions around Monte Pascoal; among them are the villages of Corumbauzinho, Águas Belas and Mata Medonha.

Mata Medonha village was established in 1951 in a region, so far completed isolated, by a family originally from Barra Velha. Other family groups, also from this original community would come later to occupy this region, making, in 1998, 143 individuals. Mata Medonha stands along the Santo Antonio River and is situated at $12 \mathrm{Km}$ from the city of Santa Cruz Cabrália. The village has 549 ha (FUNAI, 2009) with 255 individuals divided among 25 families. The members of the Mata Medonha village still maintain their knowledge of the medicinal plants although the forest has been significantly reduced and members have been spread around other areas. The aim of this paper is to document the use of medicinal plants by the Pataxó community of Mata Medonha. 


\section{MATERIAL AND METHOD}

Over three months, we interviewed all the 25 families in the village of Mata Medonha nearby settlements. Subjects were the eldest female of each family, aged 17 to 32 years old, and a respected traditional healer of the group. Conducted in Portuguese, the questionnaires gathered information about plant names, frequency of use, plant parts and preparation methods. The interviews employed an open discourse method, which best suited the natives' preferences. Although a great number of plants were cited for spiritual use, they were not included in this study. All the interviews were accompanied by the Cacique of the tribe, who took us to the families houses, some accessible only by canoe.

We were not granted permission by FUNAI to collect the plants in Mata Medonha. According to that, the plants were collected at the Botanical Garden of Salvador-BA (which has an ethnobotanic space for the cultivation of native indigenous species), Camaçari and Santo Antônio de Jesus districts, and brought to the Botanic Department of Universidade Federal da Bahia (UFBA) for taxonomical identification. The Classification system used was the APGII (Angiosperm Phylogeny Group). Voucher species were deposited at the Alexandre Leal Costa Herbarium (ALCB) of UFBA.

A bibliographic review was performed through scientific literature sites (Library of Medicine, Scientific Electronic Library Online and Portal Periódicos CAPES) using species and therapeutic properties as search words, with no limit of publication year.

These records were published with the approval of the Council of the Genetic Patrimony (CGEN), and cleared by the Ethics Committee of Research (CEP/MCO/UFBA). The access of any information in this paper for bioprospection or technologic development must be authorized by the CGEN.

\section{RESULT}

Forty eight species were described, including vernacular name, voucher number, family, species, indication of treatment and form of use (Table 1). The plant parts used included: leaves $(54 \%)$, multiple plant parts (19\%), stems (8\%), branches (6\%) and fruit (4\%). Isolated flowers, seeds, tubercles, roots and buds were used in less than $2 \%$ of medications. The forms of preparation used were: decoction ( $42 \%)$, bath $(13 \%)$, maceration ( $8 \%)$, raw $(4 \%)$, and a combination of different forms (16\%), including syrup, plaster, wine, smoke or vapor inhalation. The medicinal uses of the plants varied widely: flu, congestion, and bronchitis $(21 \%)$, pain $(19 \%)$, stimulant $(8 \%)$, anesthetic, cicatrisation, diabetes and snake bites (less than 6\%), and those used only by women Argeratum conyzoides (mentrasto) for premenstrual pain and Zornia diphylla (arrozinha) for vaginal itching. Plants referred as for spiritual use were not described.

\section{Preparation methods}

Decoction - Plants were added to boiling water in a clay pot, removed from heat, cooled, strained through clothe, then drunk twice per day.

Maceration - Plants were smashed with a pestle and the resulting leaf juice was dropped over the affected area (ear infection) or drunk pure (one spoonful for bronchitis and germs).

Baths - Similar to decoction, but a larger amount of plants were heated in a large basin with water. The water was applied lukewarm to the affected area or the whole body.

Syrup - Plants were cooked in boiling water for five minutes in the same proportion as decoction, with 2 full spoons of sugar cane (called rapadura) per cup of the preparation.

Plaster - Plants were crumbled with a pestle until a homogenous paste was obtained and applied directly over the wounds.

Alcolatrura - Plants were crushed, mixed with cachaça (a sugar-cane distillate similar to rum), incubated for a few weeks, and then drunk in small doses (1-2 spoons) twice a day.

Stem sieve - Applied directly to the wounds for cicatrisation, Anacardium occidentale only.

Wine - Tuber roots were shredded and incubated in human saliva for a few weeks until fermentation. The wine was taken one to two spoons a day.

Inhalation - Similar to baths, but vapor inhaled for 30 minutes or until headache relieved.

The plants were well distributed among 28 different families. The most cited were Asteraceae (4), Verbenaceae (3), Fabaceae (3), Anarcadiaceae (3) and Lamiaceae (3).

The search for scientific evidence of the plants properties through bibliographic research demonstrated that $31 \%$ of them have therapeutic properties confirmed and/or chemical compound (s) related to those properties isolated (Table 2).

\section{DISCUSSION}

The majority of the medicinal plants cited by the Pataxós from Mata Medonha community have not been studied as possible therapeutic agents. Due to high effectiveness, according to individuals of the community, several described plants should be considered for pharmacological tests including the cajueiro (Anacardium occidentale L.) sieve, which has a very fast cicatrisation effect for deep wounds; the juburandi, (Piper asimum (Spr.) Angely) used by the Pataxó as a tooth anesthetic, and the parreira-do-

Rev. Bras. PI. Med., Botucatu, v.14, n.1, p.84-91, 2012. 


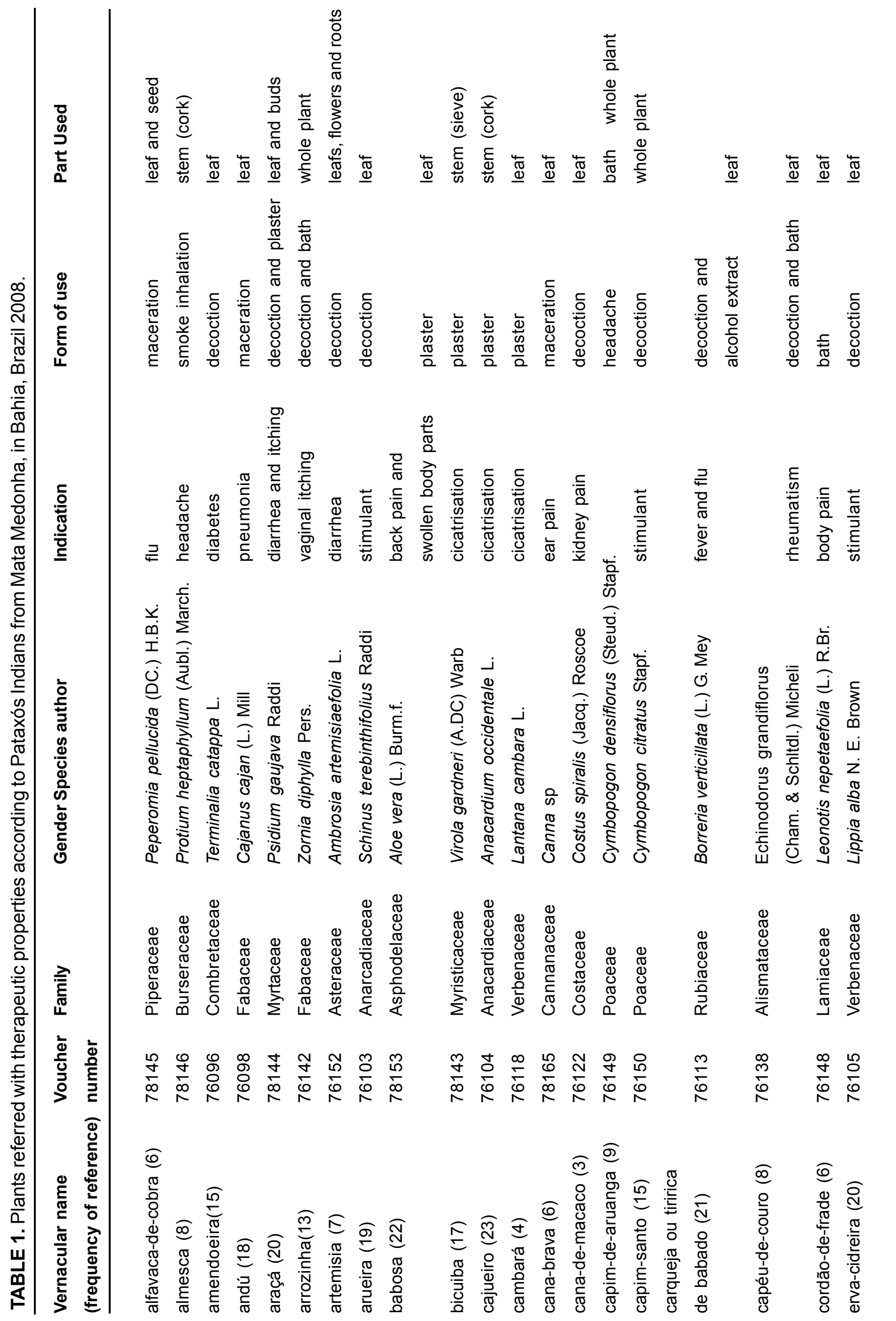

Rev. Bras. PI. Med., Botucatu, v.14, n.1, p.84-91, 2012. 


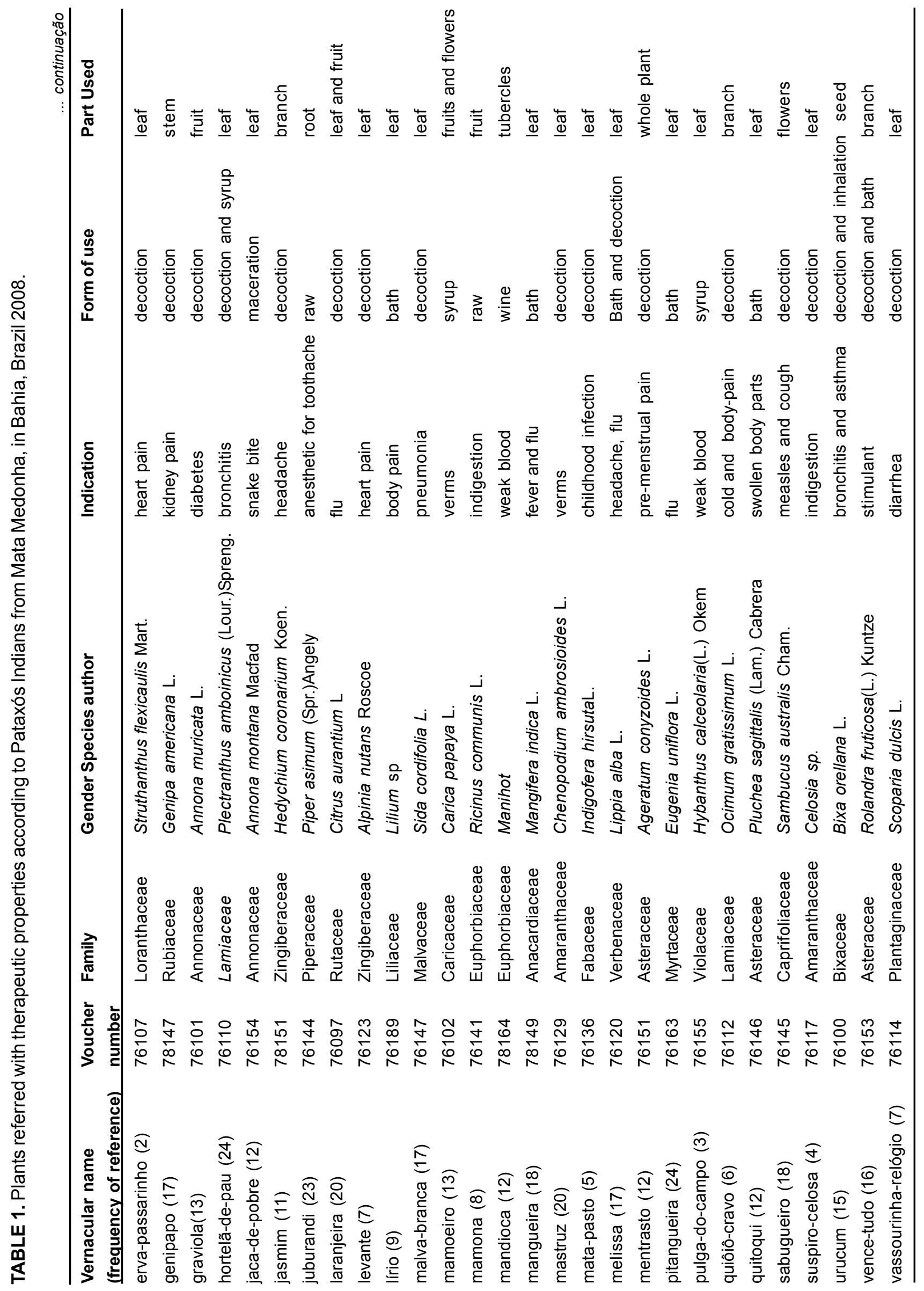

Rev. Bras. PI. Med., Botucatu, v.14, n.1, p.84-91, 2012. 
TABLE 2. Plants referred by Mata Medonha community that had therapeutic properties confirmed or related chemical compound(s) isolated/identified.

\begin{tabular}{|c|c|c|c|}
\hline Species & Indications & Therapeutic properties and chemical compounds related & Authors \\
\hline $\begin{array}{l}\text { Peperomia } \\
\text { pellucida } \\
\text { (DC.) H.B.K. }\end{array}$ & flu & $\begin{array}{l}\text { aqueous extract of the aerial part of the plant showed anti- } \\
\text { inflammatory and analgesic activity in rats and mice }\end{array}$ & $\begin{array}{l}\text { Arrigoni-Blank et } \\
\text { al. (2004) }\end{array}$ \\
\hline $\begin{array}{l}\text { Protium } \\
\text { heptaphyllum } \\
\text { (Aubl.) March. }\end{array}$ & headache & $\begin{array}{l}\text { phytochemical investigation of the resin, fruits, leaves, and } \\
\text { trunk led to the isolation of the monoterpene } p \text {-menth-3-ene- } \\
1,2,8 \text {-triol }\end{array}$ & $\begin{array}{l}\text { Bandeira } \\
\text { et al. (2002) }\end{array}$ \\
\hline $\begin{array}{l}\text { Terminalia } \\
\text { catappa L. }\end{array}$ & diabetes & the leaves are rich in tannins that are reported to be antidiabetic & $\begin{array}{l}\text { Nagappa et al. } \\
(2003)\end{array}$ \\
\hline $\begin{array}{l}\text { Aloe vera }(L .) \\
\text { Burm.f. }\end{array}$ & $\begin{array}{l}\text { back pain } \\
\text { and swollen } \\
\text { body }\end{array}$ & $\begin{array}{l}\text { shows increased bioavailability of vitamins } C \text { and } E \text {, two } \\
\text { antioxidants with possible effects on pain and swelling }\end{array}$ & $\begin{array}{l}\text { Vinson et al. } \\
(2005)\end{array}$ \\
\hline $\begin{array}{l}\text { Anacardium } \\
\text { occidentale L. }\end{array}$ & cicatrisation & $\begin{array}{l}\text { proved to cause cicatrisation in patients with wounds caused } \\
\text { by leishmaniasis }\end{array}$ & $\begin{array}{l}\text { Vera et al. } \\
(2001)\end{array}$ \\
\hline $\begin{array}{l}\text { Lantana } \\
\text { cambara L. }\end{array}$ & $\begin{array}{l}\text { head } \\
\text { wounds }\end{array}$ & $\begin{array}{l}\text { The extract produced an inhibition of anti-inflammatory and } \\
\text { analgesic effect in rats }\end{array}$ & $\begin{array}{l}\text { Uzcátegui } \\
\text { et al. (2004) }\end{array}$ \\
\hline $\begin{array}{l}\text { Mangifera } \\
\text { indica L. }\end{array}$ & fever and flu & $\begin{array}{l}\text { different polyphenols found in Vimang could account for the } \\
\text { antinociceptive and anti-inflammatory actions }\end{array}$ & $\begin{array}{l}\text { Garrido et al. } \\
(2001)\end{array}$ \\
\hline $\begin{array}{l}\text { Leonotis } \\
\text { nepetaefolia } \\
\text { (L.) R.Br. }\end{array}$ & body pain & $\begin{array}{l}\text { hydroalcoholic and tea extracts of stems showed relaxant } \\
\text { effect in guinea pig muscle }\end{array}$ & $\begin{array}{l}\text { Calixto et al. } \\
(1991)\end{array}$ \\
\hline $\begin{array}{l}\text { Plectranthus } \\
\text { amboinicus } \\
\text { (Lour.)Spreng. }\end{array}$ & bronchitis & $\begin{array}{l}\text { Essential oil contains thimol and carvacrol with anti-microbial } \\
\text { properties, possibly contributing to treating lung pathologies }\end{array}$ & $\begin{array}{l}\text { Torres et al. } \\
(2005)\end{array}$ \\
\hline $\begin{array}{l}\text { Annona } \\
\text { montana } \\
\text { Macfad }\end{array}$ & snake bite & $\begin{array}{l}\text { phenanthrene-1,4-quinone, annoquinone-A, along with } \\
\text { parietin (physcion) and beta -sitostenone were isolated from } \\
\text { the stem bark and demonstrated potent antimicrobial activity } \\
\text { and cytotoxicity in human tissue culture assay }\end{array}$ & $\begin{array}{l}\text { Wu et al. } \\
(1987)\end{array}$ \\
\hline $\begin{array}{l}\text { Sida } \\
\text { cordifolia L. }\end{array}$ & pneumonia & $\begin{array}{l}\text { when tested against Staphylococcus aureus, Staphylococcus } \\
\text { epidermidis, Candida guilliermondii and Trichosporon inkin } \\
\text { the essential oil showed significant antimicrobial activity }\end{array}$ & $\begin{array}{l}\text { Nunes et al. } \\
(2006) \text {; Franzotti } \\
\text { et al. (2000) }\end{array}$ \\
\hline $\begin{array}{l}\text { Carica } \\
\text { papaya L. }\end{array}$ & verms & $\begin{array}{l}\text { plant extracts exhibited an anti-amoebic activity. The highest } \\
\text { activity was obtained from root bark }\end{array}$ & $\begin{array}{l}\text { Tona et al. } \\
(1998)\end{array}$ \\
\hline $\begin{array}{l}\text { Chenopodium } \\
\text { ambrosioides L. }\end{array}$ & verms & $\begin{array}{l}\text { infusions of Chenopodium ambrosioides contain a } \\
\text { nematocide(s) that is(are) not toxic to mammalian smooth } \\
\text { muscle }\end{array}$ & $\begin{array}{l}\text { MacDonald et al. } \\
(2004)\end{array}$ \\
\hline
\end{tabular}


mato, applied for cancer treatment (not collected nor identified at the request of the healers).

The medicinal plants used by the Pataxós of Monte Pacoal, were analyzed by Thomas (2001). Since Monte Pacoal is the original land of the people from the village of Mata Medonha, we compared information obtained at this work with our data. 92 plants, belonging to 48 botanic families were used for treatment of 31 diseases by the inhabitants of Monte Pascoal. Although the Indians from Mata Medonha moved from the mainland around 48 years ago, $98 \%$ of all species cited in our work were referred by the people of Barra Velha. This indicates that the information about the medicinal plants is still maintained by their descendents who moved out to nearby villages. In another hand, $42 \%$ of the botanic families cited by them were not found in our work, probably because they are not available anymore or because the knowledge was not passed to the new generations' members that moved out.

According to an ethnobotanical study of medicinal plant use in Salvador, Bahia, the Lamiaceae family is also widely applied for treatment of metabolic disorders and heart diseases (Cunha Lima et al., 2008). This suggests the importance of this botanic family to pathologies that are typical of urban areas.

The forests of eastern coastal Brazil are considered among the most endangered habitats on earth and have been given highest priority for biodiversity conservation (Thomas et al., 2003). The plants from this forest have been the source of food and medication to Pataxós for many years, and now, with only $3.5 \%$ of the vegetation (compared to 1912) little are left for the native communities of the region. The tribe is small and shrinking and the youngest generation is being lured to the cities. In a developing country like Brazil, traditional medicine is very important because the plants are cheaper than pharmaceutical drugs. According to that, further study of these traditional medicines is necessary, not only for pharmaceutical purposes, but to maintain Brazil's rich and ancient traditions of healing.

\section{ACKNOWLEDGEMENT}

We want to thank Cacique Baiara for helping with the interviews and for field assistance. Special gratitude is expressed to the Pataxó people of Mata Medonha for their kind hospitability.

\section{REFERENCE}

AGRA, M.F.; FREITAS, P.F.; BARBOSA-FILHO, J.M. Synopsis of the plants known as medicinal and poisonous in Northeast Brazil. Revista Brasileira de Farmacognosia, v.17, n.1, p.114-40, 2007.
AGRA, M.F. et al. Survey of medicinal plants used in the region Northeast of Brazil. Revista Brasileira de Farmacognosia, v.18, n.3, p.472-508, 2008

ALMEIDA, H.M. Mineração e Meio Ambiente na Constituição Federal. São Paulo: Editora LTR, 1999. 112p.

ARRIGONI-BLANK, M.F. et al. Anti-inflammatory and analgesic activity of Peperomia pellucida (L.) HBK (Piperaceae). Journal of Ethnopharmacology, v.91, n.23, p.215-8, 2004.

BANDEIRA, P.N. et al. Metabólitos secundários, Protium heptaphyllum. Química Nova, v.25, n.6B, p.1078-80, 2002.

BEGOSSI, A.; HANAZAKI, N.; TAMASHIRO, J.Y. Medicinal plants in the Atlantic Forest (Brazil): knowledge, use, and conservation. Human Ecology, v.30, n.3, p.281-5, 2002. BEGOSSI, A. et al. Diversity of plant uses in two Caiçara communities from the Atlantic Forest coast, Brazil. Biodiversity and Conservation, v.9, p.597-615, 2000.

BEGOSSI, A. Use of ecological methods in ethnobotany: diversity indices. Economic Botany, v.50, n.3, p.280-9, 1996.

CALIXTO, J.B.; YUNES, R.A.; RAE, G.A. Effect of crude extracts from Leonotis nepetaefolia (Labiatae) on rat and guinea-pig smooth muscle and rat cardiac muscle. Journal of Pharmacy and Pharmacology, v.43, n.8, p.529-34, 1991.

COUTINHO, D.F.; TRAVASSOS, L.M.; AMARAL, F.M.M. Ethnobotanical study of medicinal plants used by the Indian communities from Maranhão - Brazil. Visão Acadêmica, v.3, n.1, p.7-12, 2002.

CUNHA LIMA, S.T. et al. Levantamento da flora medicinal usada no tratamento de doenças metabólicas em Salvador, BA, Brasil. Revista Brasileira de Plantas Medicinais, v.10, n.4, p.83-9, 2008.

CURI, M.V. Mining in native people's lands: case studies. 2005. 128p. Tese (Doutorado em Administração e Política de Recursos Minerais) - Instituto de Geociências. Universidade Estadual de Campinas. Campinas.

FERRO, D. Fitoterapia: conceitos clínicos. São Paulo: Editora Atheneu, 2006. 502p.

FRANZOTTI, E.M. et al. Anti-inflammatory, analgesic activity and acute toxicity of Sida cordifolia L. (Malvabranca). Journal of Ethnopharmacology, v.72, p.273-8, 2000.

Fundação Nacional do Índio (FUNAI). Disponível em: <http://www.funai.gov.br>. Acesso em: 22 mar. 2009. GARRIDO, G. et al. Analgesic and anti-inflammatory effects of Mangifera indica L. extract (Vimang). Phytotherapy Research, v.15, n.1, p.18-21, 2001.

GOUVEIA, A.J. A pesquisa sobre educação no Brasil: de 1970 para cá. Cadernos de Pesquisa da Fundação Carlos Chagas, v.19, p.75-9, 1976.

Instituto Brasileiro do Meio Ambiente e dos Recursos Naturais Renováveis (IBAMA). Disponível em: <http:// www.ibama.gov.br>. Acesso em: 1 de abr. 2009.

MACDONALD, D. et al. Ascaridole-less infusions of Chenopodium ambrosioides contain a nematocide(s) that is(are) not toxic to mammalian smooth muscle. Journal of Ethnopharmacology, v.92, n.2-3, p.215-21, 2004.

MILLIKEN, W.; ALBERT, B. The use of medicinal plants by the Yanomami Indians of Brazil. Economic Botany, 
v.50, n.2, p.10-25, 1996.

MILLIKEN, W.; ALBERT, B. The use of medicinal plants by the Yanomami Indians of Brazil, part II. Economic Botany, v.51, n.3, p.264-78, 1997.

MORAIS, S.M. et al. Ethno-medicinal plants of Tapeba Indians from the State of Ceará - Brazil. Revista Brasileira de Farmacognosia, v.15, n.2, p.169-77, 2005.

NAGAPPA, A.N. et al. Antidiabetic activity of Terminalia catappa Linn fruits. Journal of Ethnopharmacology, v.88, p.45-50, 2003.

NUNES, X.P. et al. Antimicrobial activity of the essential oil of Sida cordifolia L. Revista Brasileira de Farmacognosia, v.16, p.642-4, 2006.

PÁDUA, M.T.J.; COIMBRA FILHO, A.F. Os parques nacionais do Brasil. Coleção: A natureza na Iberoamérica, Rio de Janeiro: Olympio, 1989. 224p.

RODRIGUES, R.; CARLINI, E.A. Ritual use of plants with possible action on the central nervous system by the Krahô Indians, Brazil. Phytotherapy Research, v.19, n.2, p.12935, 2005.

THOMAS, W. et al. Plant endemism in two forests in southern Bahia, Brazil. Biodiversity and Conservation, v.7, p.311-22, 2001.

THOMAS, W.M.W. Vegetation types in southern Bahia. Instituto de Estudos Sócio-Ambientais do Sul da Bahia e Conservation International do Brasil, v.2, n.3, p.1-4, 2003.
TONA, L. et al. Antiamoebic and phytochemical screening of some Congolese medicinal plants. Journal of Ethnopharmacology, v.61, n.1, p.57-65, 1998.

TÔRRES, A.R. et al. Estudo sobre o uso de plantas medicinais em crianças hospitalizadas da cidade de João Pessoa: riscos e benefícios. Revista Brasileira de Farmacognosia, v.15, n.4, p.373-80, 2005.

United Nations Educational, Scientific and Cultural Organization (UNESCO). Discovery Coast Atlantic Forest Reserve, Inscribed 1999. Disponível em: <http:// whc.unesco.org>. Acesso em: 22 jan. 2009.

UZCÁTEGUI, B. et al. Anti-inflammatory, antinociceptive, and antipyretic effects of Lantana trifolia Linnaeus in experimental animals. Investigacion Clinica, v.45, n.4, p.317-22, 2004.

VERA, L.A. et al. Evaluation of the secondary bacterial infection's influence on the evolution of cutaneous leishmaniasis in Corte de Pedra, Bahia. Revista da Sociedade Brasileira de Medicina Tropical, v.34, n.3, p.233-7, 2001.

VINSON, J.A.; AL KHARRAT, H.; ANDREOLI, L. Effect of Aloe vera preparations on the human bioavailability of vitamins $C$ and E. Phytomedicine, v.12, n.10, p.760-5, 2005.

WU, T.S. et al. Annoquinone-A, an antimicrobial and cytotoxic principle from Annona, Montana. Phytochemistry, v.26, n.6, p.1623-5, 1987. 